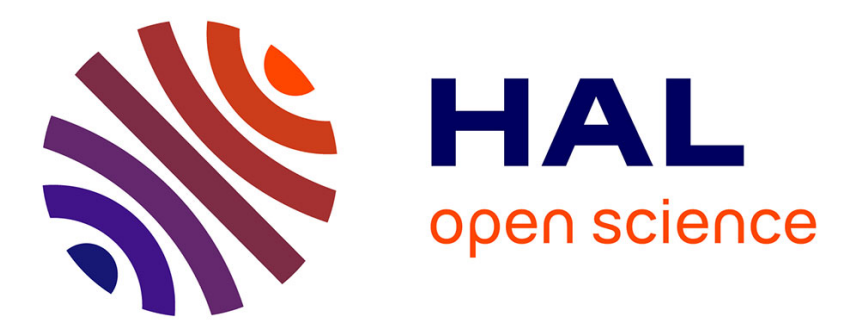

\title{
A Forgotten Chapter in the History of International Arbitration: The Slave Trade's Dispute Settlement System
}

\author{
Anne-Charlotte Martineau
}

\section{- To cite this version:}

Anne-Charlotte Martineau. A Forgotten Chapter in the History of International Arbitration: The Slave Trade's Dispute Settlement System. Leiden Journal of International Law, 2018, 31 (2), pp.219241. 10.1017/S0922156518000158 . hal-01677425

\section{HAL Id: hal-01677425 \\ https://hal.science/hal-01677425}

Submitted on 25 Aug 2021

HAL is a multi-disciplinary open access archive for the deposit and dissemination of scientific research documents, whether they are published or not. The documents may come from teaching and research institutions in France or abroad, or from public or private research centers.
L'archive ouverte pluridisciplinaire HAL, est destinée au dépôt et à la diffusion de documents scientifiques de niveau recherche, publiés ou non, émanant des établissements d'enseignement et de recherche français ou étrangers, des laboratoires publics ou privés. 


\title{
INTERNATIONAL LEGAL THEORY
}

\section{A Forgotten Chapter in the History of International Commercial Arbitration: The Slave Trade's Dispute Settlement System}

\author{
ANNE-CHARLOTTE MARTINEAU*
}

\begin{abstract}
This article is part of the ongoing efforts to write a critical history of international arbitration in commercial and investment matters. It examines the ways in which the Spanish crown and its concessionaries set up a mechanism to settle legal disputes pertaining to the transatlantic slave trade. The transformation of asientos de negros from limited royal contracts to large-scale monopolies awarded to foreign chartered companies during the sixteenth, seventeenth and early eighteenth centuries was accompanied by the creation of an international commercial arbitration system. Why was this system set up, how did it work, and what was its faith? The overall aim of the article is to invite international lawyers to rethink the history of international arbitration and pay closer attention to the 'private' dimensions of formal and informal imperialism. It also attempts to bridge the historical investigation and contemporary commentary. In the conclusion, I argue that this study allows us, in a mirroring effect, to question the idea that today's dispute settlement mechanism was conceived as a means to 'depoliticize' international investment law. What the introduction of arbitration achieves is to place some fundamental questions out of sight. Today, as in the past, arbitrators work from within the system; their work rests on a series of unspoken - and yet highly political - premises about the organization of economic life and the distribution of values.
\end{abstract}

\section{Keywords}

arbitration; history; international investment law; slavery; slave trade

\section{INTRODUCTION}

Investment law and adjudication has been said to be 'one of the fastest growing fields of international economic law'. 'Much of our attention has turned to the phenomenon of transnational arbitrations between private economic actors and public law bodies. This has not come without criticism. In recent years, the Transatlantic Trade and Investment Partnership and the EU-Canada Comprehensive Economic and Trade Agreement triggered a publicized and heated debate over investor-state

* CNRS Research Fellow, Ecole Nationale Supérieure, Paris [martineauac@ hotmail.com]. I would like to thank Martti Koskenniemi, Mario Prost, Immi Tallgren, and Geoff Gordon for their comments on previous drafts.

I P. Juillard, 'The Law on International Investment. Can the Imbalance Be Redressed?', (2008-2009) Yearbook on International Investment Law \& Policy 273, at 273. 
arbitration as a mechanism of global regulatory governance. ${ }^{2}$ Is there a need for such mechanism between economies with well-functioning legal systems? Why privilege a private justice system over courts of sovereign states? One striking aspect of these debates is the absence of historicization. Little exploration has been made of history. The absence of extensive historical work is not wholly accidental. At times, the self-proclaimed lack of history has served to justify the system in place. To say that 'international investment law is a very young discipline, with the length of its existence appropriately measured in years, rather than decades, let alone centuries'3 means that any problem should be excused as a beginner's mistake. Alternatively, the history of international investment law has also been presented in a bold or sweeping linear fashion ('the uniqueness of the current IIA [international investment agreements] network is a product of an historical evolution going as far back as the Middle Ages'4) so as to suggest that what is relevant is really only the 'era of modern investment treaties [which] began in I959'. ${ }^{5}$

One notorious exception to this trend is Kate Miles's book, The Origins of International Investment Law, in which she showed that the field did not emerge in I 959 with the advent of bilateral investment treaties. ${ }^{6}$ She traces the origins of international investment law back to the seventeenth century, when Europeans developed legal tools to protect expanded conceptions of property and promote the interests of capitalists investing abroad. That today's regime protects investment at the expense of other societal and environmental interests, Miles argues, is a direct consequence of its historical roots in colonialism and imperialism. The contribution of this book to the field is undeniable, ${ }^{8}$ and it should be commended for having situated the discussion at the interface of capitalism and imperialism. That said, much remains to be done to uncover the long-standing and complex relationship between the state and the merchants. For Miles's account of the development of an international law on foreign investment rests solely on sovereign power: In her story, merchants are secondary actors whose interests are too often subsumed by or simply aligned with that of their national states. This is a rather poor description of the intricate

2 See S.Schill, ‘Towards a Constitutional Law Framework for Investment Law Reform’, EJIL: Talk!, 5 January 20I 5 , available at www.ejiltalk.org/towards-a-constitutional-law-framework-for-investment-law-reform/. For a concise summary of contemporary debates see also F. Baetens, 'The Oxford Handbook of International Investment Law', (2009) 20(3) EJIL 939.

3 T. Cole, The Structure of Investment Arbitration (2013), xiii.

4 A. Newcombe and L. Paradell, Law and Practice of Investment Treaties. Standards of Treatment (2009), 2.

5 R. Dolzer and C. Schreuer, Principles of International Investment Law (2012), 6. On the continuity thesis see A. De Nanteuil, Droit international de l'investissement (2014), 28.

6 M. Sornarajah had already paved the way in The International Law on Foreign Investment (I994). See also A. Anghie, Imperialism, Sovereignty and the Making of International Law (2004); J. Gathii, 'War's Legacy in International Investment Law', (2009) I I International Community Law Review 252.

7 These legal tools included friendship, commerce, and navigation treaties, unequal treaties, concessions, and the de jure subjugation of non-Western peoples and lands to Europeans. K. Miles, The Origins of International Investment Law: Empire, Environment, and the Safeguarding of Capital (2013).

8 As noted by several reviewers, including D. Schneiderman, 'Kate Miles. The Origins of International Investment Law: Empire, Environment, and the Safeguarding of Capital', (20I4) 25 EJIL 942; M. Fakhri, 'The Origins of International Investment Law: Empire, Environment, and the Safeguarding of Capital. By KATE MILES', (2015) I 8 Journal of International Economic Law 697; and J. Fahner, 'The Contested History of International Investment Law: From a Problematic Past to Current Controversies', (2015) I 7 International Community Law Review 373. 
relationship that public power and private ownership developed in setting up a global regime for the protection of foreign property and investment. If we want to acquire a more thorough and realistic understanding of the ways in which legal instruments and institutions have been developed to organize global commercial activities, we need to look beyond interstates relations; attention should be directed to what Martti Koskenniemi has called 'the relations of sovereignty and property'. 9

In this article, I want to add to the ongoing efforts to write the history of international arbitration in commercial and investment matters by including this missing dimension of entanglement (sovereignty/property). I will examine in close details the ways in which the Spanish crown and its concessionaries set up a mechanism to settle legal disputes pertaining to the transatlantic slave trade. It is well-known that the slave trade caused the forced migration of 12 to I 5 million African people over five centuries. ${ }^{\text {IO }}$ This was not carried out outside law and order. From the very beginning, European states and merchants organized it within a (national and international) legal framework. The slave trade's legal basis can be found in the history of asientos de negros, namely, the contracts by which the Spanish crown granted an individual, a company or another state the privilege - and often the monopoly to supply African slaves to the Spanish colonies in America. ${ }^{\text {II }}$ What is much less known is the dispute settlement mechanism that pertained to the slave trade. ${ }^{\text {I2 }}$ I will show that the transformation of asientos de negros from limited royal contracts to large-scale monopolies awarded to foreign chartered companies during the course of the sixteenth, seventeenth and early eighteenth centuries was accompanied by the creation of an international commercial arbitration system.

Such a system did not exist at the turn of the sixteenth century, when the Spanish crown decided to grant individual licences to import black slaves to the Americas. Rapidly, almost all of the licences fell into Portuguese hands, since they monopolized the sources of supply in Africa. This triggered hostility from the Sevillian trading establishment. But having the slave trade run by Portuguese subjects was an unexpected and much welcome source of revenue for the Spanish king, who commissioned specific judges to safeguard his interests (Section 2). With the revolution of Portugal in I640, the slave trade had to be organized differently. Refusing to deal directly with the Dutch or the English - the largest slave traders by then - the Spanish authorities were drawn by the project of two Genoese bankers. The latter insisted on hiring private judges to guarantee the execution of their contract. From

9 M. Koskenniemi, 'Expanding Histories of International Law', (20I6) 56 American Journal of Legal History I04.

ro The literature is considerable. See, among many others, R. Blackburn, The Making of New World Slavery. From the Baroque to the Modern, I492-I800 (20I0); H. Klein, The Atlantic Slave Trade (I999); B. Solow (ed.), Slavery and the Rise of the Atlantic System (I99I).

i For a recent account see A. Weindl, 'The Asiento de Negros and International Law', (2008) io Journal of the History of International Law 229.

I2 The slave trade has been the topic of an impressive number of historical and legal studies. While I have learned a great deal from the historical studies, I find that law - including the workings of the dispute settlement system - tends to stay in the background. Unsurprisingly, legal scholars have looked much more closely at the legal rules, processes, and institutions that were put in place. Nonetheless, they too often portray the evolution of the slave trade's legal regime as a progressive narrative that moved from the national legal sphere to the international legal sphere, and from a mercantile colonial system to free trade. See G. Scelle, Histoire politique de la traite négrière aux Indes de Castille. Contrats et traités d'Assiento (I906). 
that point on, all slave trade legal issues would be resolved through a separate mechanism available both in the imperial centre and the colonies (Section 3). As foreign chartered companies became more and more involved, the turn to international arbitration intensified. This evolution culminated in I 7 I3, when Spain and England chose arbitration as the dispute settlement system par excellence to resolve commercial problems that might arise in relation to the English South Sea Company's slave trading operations in Spanish America (Section 4).

While the focus of the article is historical, the interest feeding it lies in the present. ${ }^{\mathrm{I} 3}$ The rise of international investment and commercial arbitration has generated a number of concerns. Critics have pointed out that this type of dispute resolution is technically poor, that it strengthens the hands of powerful companies, and that it bypasses national judicial systems in favour of an elite group of arbitrators. ${ }^{\text {I4 }}$ In response to these critics, many actors in the field have put forth small-scale or targeted reforms, often of a procedural nature. One frequently-made suggestion is that we should strengthen arbitrator selection procedures instead of moving away from party-appointed arbitrators. 'There is no need to gut the arbitration selection system to fix it'. ${ }^{15}$ It is precisely this kind of reforming move that I want to question by looking at the slave trade's dispute settlement system. It appears that many aspects of today's debate are akin to the set of issues that emerged as the slave trade's dispute settlement system was put into place and practiced. In my conclusion, I will address the question: What does it mean that similar legal issues arose already in the sixteenth, seventeenth, and eighteenth centuries, in relation to the commercial enterprise that epitomized the most exploitative form of globalization?

\section{Portuguese trading NETWORKS AND THE EARLY LiCENCING SYSTEM}

In I 5 I3, the Spanish crown issued the first individual licences for the importation of 'a great multitude of blacks to help the Indians in the work of the mines, the tillage of the land ... and other husbandry'. ${ }^{16}$ The royal licencing system was meant to respond to the growing demands on the labour force in the West Indies and to find an alternative to the system of forced labour of the Indian population that had

I3 '[H]istorical work is about the present'. A. Kemmerer, "We do not need to always look at Westphalia ... ” A Conversation with Martti Koskenniemi and Anne Orford', (2015) I 7 Journal of the History of International Law I, at 3 .

I4 See Public consultation on investor-state arbitration in TTIP - Comment, signed by renowned legal scholars, July 20I4, available at www.kent.ac.uk/law/downloads/ttip_isds_public_consultation_final.pdf. See also, from different angles, S. Puig, 'Social Capital in the Arbitration Market', (20I4) 25 EJIL 387; G. Van Harten, 'TWAIL and the Dabhol Arbitration', (20I I) 3 Trade, Law and Development I3 I; J. Viñuales, 'Foreign Investment and the Environment in International Law: An Ambiguous Relationship', (2009) 80 BYBIL 244.

I5 C. Giorgetti, 'Who Decides Who Decides in International Investment Arbitration?', (2014) 35 University of Pennsylvania Journal of International Law 43 I, at 43 I.

I6 AGI Indiference 746 (I 599), cited in T. Seijas, Asian Slaves in Colonial Mexico: From Chinos to Indians (2014), Ioo. Black slaves were already present in the West Indies. They had arrived with the first conquest expeditions as servants and auxiliaries. In the early decades of colonial rule, Spaniards were also granted licences to take small numbers of slaves from the Iberian Peninsula for their own personal service. 
come under attack in Europe. ${ }^{17}$ Licences were to be valid for a period of time and granted, for a set number of slaves, to Castilian merchants, who would then arrange a slaving voyage. ${ }^{18}$ We know that the start of the operation was rather amateurish: The Spanish king gave most licences to his favourites, who did not care much for the trade. ${ }^{\text {I9 }}$ As they generally did not have any experience with slave trading, they sold their licences to third parties or used them for financial speculation. 'A roaring trade in licences for the import of fixed numbers of black slaves actually began', explains Andrea Weindl, 'without resolving the problem of labour shortages in the New World'. ${ }^{20}$

From I 532 onwards, the Casa de Contratación de Indias (House of Trade) in Seville took charge of managing the slave trade, including the issuance of and control over slave-trading licences. That the Spanish crown decided to regulate the slave trade through the House of Trade, just like any other colonial mercantile activity, meant not only that it sought to subject the importation of black labour to a strict governmental control - against the settlers' desire - but also that it sought to recover revenues from the slave trade. ${ }^{2 I}$ Realizing the considerable financial gains that could be made, Spanish authorities increased the price of licences per slave from two ducats in I5I3 to 30 ducats and 20 reals customs duty in I56I. ${ }^{22}$ This heavy hands-on involvement of the Spanish state in the operation of the slave trade would last until the last quarter of the eighteenth century.

With the licencing system being set up, more and more legal issues arose. In Spain, the Real y Supremo Consejo de Indias (Council of the Indies) was the highest judicial organ in matters involving the Indies. In the colonies, it was the Royal Audiencias (courts of justice), presided over by the viceroys, that dealt with commercial disputes. Almost every cédula (decree) promulgated by the Crown in relation to the slave trade gave rise to judicial proceedings in the Americas. One example is the royal decree adopted in May I556 that tried to address settlers' concerns about high tariffs by fixing a maximum selling price for slaves. As soon as they learned about the decree in July I557, buyers in Mexico filed complaints against slave traders, asking for the recovery of overpayments or a decrease of obligations. The Audiencia had to decide whether the fixed price applied to slaves who were bought, shipped and/or sold during the ten-month lapse that existed between the passing of the decree in Madrid and its publication in Mexico. As the court did not know which way to go, it sought

17 Bartolomé de Las Casas (I484-I566) is among the first to have suggested and supported the substitution of Africans for Indian slavery in the Americas. Toward the end of his life, however, he grew to realize, and to regret, 'his error'. J.A. Saco, Historia de la esclavitud de la esclavitud de la raza africana en el nuevo mundo y en especial en los países americo-hispanos (I938), vol. II, at 80.

i8 G. Scelle, 'The Slave-Trade in the Spanish Colonies of America: The Assiento', (I9Io) 4 AJIL 6I2, at 6I6.

I9 Many licences were initially granted for free to reward faithful servants or to pay debts (the issue of juros). The most famous example of this practice is Charles V's grant of 4,000 licences in I 5 I 8 to a Flemish favourite, who quickly sold them to a firm of Genoese merchants for 25,000 ducats. For a thorough study of sixteenthcentury licences, see L. García Fuentes, 'Licencias para la introducción de esclavos en Indias y envíos desde Sevilla en el siglo XVI', (I982) I 9 Jahrbuch für Geschichte von Staat, Wirtschaft und Gesellschaft Lateinamerikas I.

20 Weindl, supra note II, at 232.

${ }_{21}$ E. Vila Vilar, Hispanoamérica y el comercio de esclavos (2014), I7.

22 L. Newson and S. Minchin, From Capture to Sale: The Portuguese Slave Trade to Spanish South America in the Early Seventeenth Century (2007), I8. 
advice from the Council of the Indies in Seville. ${ }^{23}$ One consequence is that it would take years for such cases to be resolved.

The involvement of foreigners was a complicating factor in the royal licencing system. Under the monopolistic system, participation of non-nationals in any kind of trade with the Indies was legally forbidden. However, the Portuguese were involved from very early on: Since Spain had no trading posts in Africa, Spaniards necessarily had to liaise with their neighbours who had privileged access to Africa. ${ }^{24}$ The steady rise in the price of slave licences in the mid-sixteenth century made Portuguese professional traders even more prominent in the operations. Their participation peaked with the occupation of Portugal by Spain between I580 and I640. Indeed, as soon as Philip II secured the throne of Portugal for himself, he began to conclude licencing agreements with his new subjects, and especially with Portuguese rendeiros (holders of the royal tax-farming contract on slave export duties in Africa). ${ }^{25}$ At that point, there were three major areas of slaving - the Cape Verde Islands, São Tomé, and Angola. Philip II signed contracts for the supply of slaves to the Spanish Indies from these three regions. In return for their licences, Portuguese rendeiros would pay the crown a percentage of their profits.

These contracts were met with growing hostility on the part of Sevillian merchants. In fact, the ever-expanding participation of the Portuguese in the slave trade triggered a heated debate in the I580s that opposed the Council of the Indies, on the one hand, to the Consulado de Sevilla, a powerful guild or consortium of Sevillian merchants, together with the House of Trade, on the other hand. The debate was not about the legitimacy of the slave trade; it was about who should benefit from it. Enriqueta Vila Vilar has shown that, by then, everyone had come to the idea that the slave trade would best be carried out by means of a monopoly contract. ${ }^{26}$ But who was to obtain the lion's share? The Council of the Indies was in favour of the Portuguese, because of their substantial capital available, direct access to the factories of Cacheu and Luanda, and the benefit of long experience. But the Consulado de Sevilla wrote to the king to warn against the infiltration of converso merchants or 'New Christians"27 in the Indies and denounce the draining away of Spanish silver. In an attempt to hold onto its declining share, the Consulado de Sevilla tried to obtain the monopoly over the administration of slave-trading licences for a period of nine years. The deal was never concluded. In I 595, the Spanish authorities signed what is now called 'the

23 Scelle, supra note I2, vol. I, at 286-7.

24 The Portuguese had established factories along the West coast of Africa starting in the fifteenth century. The Spaniards had given up their claim over Africa through the Treaty of Tordesillas (I494).

25 In Africa, the Portuguese crown farmed out the control of the slave trade and the collection of taxes to private individuals (rendeiros). The latter would conclude agreements with slave traders wishing to export Africans from their regions and collect the duties involved.

26 E. Vila Vilar, 'Los asientos portugueses y el contrabando de negros', (1973) 30 Anuario de Estudios Americanos 557 , at 559.

27 Most Portuguese contractors who obtained the asiento between I 580 and I 640 were converso merchants, who had been forced by the king of Portugal to convert from Judaism to Catholicism in I 497. Many of them had come to live in Spain and in Spanish America, where they enjoyed relative freedom. Gradually, however, they would come to live in fear of the Inquisition. See I. Jonathan, Diasporas within the Diaspora. Jews, Crypto-Jews and the World Maritime Empires (I IIO-I740) (2002). For the trajectory of one converso family - the Gramaxo family - deeply involved in the slave trade, see J. Vance Roitman, 'Sephardic Journeys. Travel, Place and Conceptions of Identity', (2009) I I(I-2) Jewish Culture and History 208. 
first important asiento de negros ${ }^{28}$ with Pedro Gomez Reynel, a wealthy courtier from Lisbon, whose financial offer was deemed more advantageous. Reynel undertook the obligation to deliver 4,250 slaves to America per year, for a duration of nine years. In return, he agreed to finance an amount of Ioo,ooo ducats - a huge amount at the time - to be paid annually to the crown. ${ }^{29}$

This contract is usually viewed as a stepping stone because it embodied all the characteristics of subsequent contracts. ${ }^{30}$ But this asiento is also important because it introduced jueces de comisión in the slave trade legal framework. Specific judges were commissioned either by the king (in Spain) or the viceroy (in the Indies) to hear all asiento-related cases, and thus 'to avoid the drawbacks of judicial delays'. ${ }^{31}$ These were not private judges insofar as they were selected from ordinary judges and worked together with a warrant officer and a clerk who were also specially appointed. Neither was it a strictly separate or exclusive judicial procedure, given that Reynel and all licences holders kept the right to address themselves to ordinary courts. Let us recall that the institution of juez de comision was well established in Spain: The infant state administration was in the hands of officers and commissioners who were, respectively, the ordinary and extraordinary agents of the monarch. ${ }^{32}$ Officers tended to be proprietors of their posts and thus fairly independent; besides, the honour associated to their posts meant that officers were able to grow rich and could be ennobled; 'often they were not very diligent in performing their tasks'. ${ }^{33}$ In comparison, commissioners had duties limited by their letters of commission, which could be revoked at any moment. Their more vulnerable status and the greater docility that resulted from it made them the administration's main instruments. This is why the introduction of jueces de comision in the slave trade operation should be seen, first and foremost, as a measure meant to ensure the respect of the monarch's will. ${ }^{34}$

Busto de Bustamante, the king's counsel at the House of Trade, was commissioned to supervise the implementation of Reynel's asiento. ${ }^{35}$ As the main juez de comision, he was entitled to visit ships prior to their departure to America and upon their return to the Iberian Peninsula, and report any case of fraud and corruption. His jurisdiction extended beyond the termination of the contract, so as to be able to

28 Scelle supra note I2, vol. I, at 347 .

29 This was not a monopoly: even though Reynel was entitled to deliver by himself the number of slaves whose trade he would not sell through licences, he could not refuse the disposal of licences, for which a ceiling amount had been stipulated to the merchants of Seville and Lisbon. A number of licences were also set aside for allocation at the king's discretion. The asiento specified the places of importation and the points of delivery, as well as the navigation system. Slaves could be transported in ships unconnected to the Spanish Treasure fleet system, but only with Portuguese or Castilian crews, and with the obligation 'not to trade in the Indies'.

30 Scelle, supra note i 2, vol. I, at 358-9.

3I Vila Vilar, supra note 2I, at 75.

32 See I. Gómez González, 'Más allá de la colegialidad. Una aproximación al juez de comisión en la España del antiguo régimen', (20I I) 37 Chronica Nova 2 I ; R. Mousnier, 'La fonction publique en France du début du seizième siècle à la fin du dix-huitième siècle', (I979) 26I(2) Revue historique $32 \mathrm{I}$.

33 M. Delon (ed.), Encyclopaedia of the Enlightenment (2002), 203.

34 One might argue that it facilitated the work of future asentistas when they sought to introduce private judges who would take their concerns into consideration. This is Scelle's argument, supra note I2, vol. I, at 360.

35 Vila Vilar, supra note 2I, at 76. 
recover any remaining debt and prosecute those responsible of fraudulent activities. Unfortunately, little is known about the decisions Bustamante took in relation to the asiento. More has been written on the uneasy relationship Reynel maintained with his creditors - a handful of wealthy bankers ${ }^{36}$ - and on the men he put in place to run operations. In addition to employing his two brothers as general managers in Seville, he had agents working for him in Cartagena, Vera Cruz, Puerto Rico, Bahia, and Rio de Janeiro. This indicates that from (at least) I595 onwards, Portuguese asentistas built an administrative and financial infrastructure across the Hispanic Empire. ${ }^{37}$ Their agents came to play a central role in the system, managing both the legal and illegal slave trade. Although their obligations and duties were duly set out in the asiento, these middlemen were very powerful, 'vested with full powers of the asentistas, they were actually the ones doing the business'. ${ }^{38}$

And yet, Reynel's enterprise did not go as planned. His agents faced strong resistance in the Americas, and Reynel saw his asiento revoked in I60I after he was found guilty of 'colluding with smugglers' ${ }^{39}$ For a decade, the Spanish administration struggled to find a reliable (and lasting) asentista. ${ }^{40}$ These repeated setbacks led the Consulado de Sevilla to regain leverage with the king. Complaints against the involvement of Portuguese merchants in the Indies had continued, uninterrupted, to emanate from the ranks of Castilian officialdom. ${ }^{4 \mathrm{I}}$ This time, their criticism focused on the navigation system. ${ }^{42}$ A special Junta was set up to review the navigation laws. How should transportation be done? The Consulado de Sevilla made the following proposal: In addition to prohibiting navios sueltos, the authorities should require all slave ships to transit through Seville on their way from Africa to America. The reaction from Lisbon was quick - not only merchants but also state officials

${ }^{36}$ To fund his operation, Reynel needed sponsors. He contracted his most important loans to Cosme Ruiz, a Castilian merchant who directed an important commercial network in the region. H. Lapeyre, 'Le trafic négrier avec l'Amérique espagnole', in Homenaje a Jaime Vicens Vives (1967).

37 For their reliance upon an important transnational network of merchants and bankers, see A. De Almeida Mendes, 'Les réseaux de la traite ibérique dans l'Atlantique Nord', (2008) 4 Annales 739.

38 Vila Vilar, supra note 2I, at 8I. See also Newson and Minchin, supra note 22, at 2 I.

39 Scelle, supra note I2, vol. I, at 383.

40 Soon after the annulment of Reynel's contract, a new asiento was let to Juan Rodríguez Coutinho, governor of Angola and holder of the royal tax-farming contract there. The terms of the agreement were much stricter, and Coutinho ran almost immediately into legal and financial difficulties; many lawsuits were brought against him, for instance, by holders of previously issued licences and by Reynel himself. Upon his unexpected death in 1603 , his brother and business partner took over. At that point, the difficulties in assuring the timely transfer of credit, silver, and rents were such that the new asentista was forced into bankruptcy in I607. To make the situation worse, the public bid that the House of Trade launched in 1609 for the slave trade administration received only two applications. The one who won the contract - a certain Augustín Cuello rapidly turned out to be a mere front man for a Portuguese merchant who was spending time in prison for debt.

4I See F. Bethencourt, 'The Iberian Atlantic: Ties, Networks, and Boundaries', in H. Braun and L. Vollendorf (eds.), Theorising the Ibero-American Atlantic (2013), 28; H. Thomas, The Slave Trade. The Story of the Atlantic Slave Trade, I440-I870 (I997), I63.

42 In I6 I I, Sevillian merchants sent a brief to the Council of the Indies asking to end the possibility of Portuguese ships sailing on their own, i.e., outside of the Spanish Treasure fleet, and by the most direct route, i.e., directly from Lisbon, Cape Verde Islands or Angola to the Indies. They argued that to allow slave ships to leave directly from the port of Lisbon or from Portuguese possessions in Africa enabled captains to escape paying taxes, given that officials in Lisbon and in Africa were less punctilious than those in Seville. For an extensive résumé of the debate, see Scelle, supra note I2, vol. I, at 4I 2-I9. 
opposed such a 'preposterous project'. ${ }^{43}$ After some hesitation, the Junta endorsed the solution put forth by the Consulado de Sevilla, so that between I6I I and I6I5, all slave ships could go to the Indies only via Seville. This heavy-handed attempt to re-boost Seville's commercial activities, however, merely suppressed the legal trade and aided a flourishing contraband trade. The income shortfall for the Spanish treasury was so tremendous that another Junta was established to discuss the future organization of the slave trade. In March I6I4, high officials from both the Spanish and the Portuguese governments met at the house of the President of the Council of Castile to discuss the matter. ${ }^{44}$ The conditions under which the following asiento was concluded a year later with Antonio Fernández Delvás show that a compromise had been reached. 45

As this incident makes clear, the slave trade had become a matter of utmost importance to both governments. By allowing Delvás - a Portuguese slave trade magnate - to be in charge of the operations, Madrid hoped to increase its benefits while responding to the labour shortage in the colonies. For a while, its wishes seemed to come true: Within three years 'more slaves arrived in the Indies than in any previous period'. ${ }^{46}$ So why did Delvás have to declare bankruptcy in I62 I? Not everyone was happy with the benefits he made. ${ }^{47}$ The traffic had become almost impossible to control, and the Royal Treasury complained repeatedly to the Council of the Indies about massive losses incurred due to fraud. But if the state could not count on its officers to supervise the implementation of the asiento, neither could Delvás. Even though the latter made use of all legal means available to him, including the use of jueces de comisión, he could not prevent royal officials from throwing a spanner in the works:

In Seville there were constant disagreements about the issuance of registers and the boarding of crews, provisions or goods ... In the Indies, things were even worse. In the ports of permission, [officers] were as unfaithful to the interests of the King as to those of Delvas. Because officials were working hands and hands with interlopers, they either had to be bought or one would have them as enemies ... In the ports that were not permitted, fraud was almost ubiquitous. Pretexting bad weather or damages, owners of slave ships with no license could come and disembark with the connivance of royal officers. ${ }^{48}$

The point that I want to make is that it was not clear how one could ensure a rightful course of actions in such circumstances. The next asentista, Manuel Rodríguez Lamégo, hired his own coast guards and police force in the Indies to oversee the

\footnotetext{
43 Vila Vilar, supra note 2I, at 572.

44 The first meeting involved the President of the Council of the Indies, the President of the Council of Finance, and two members of the Council of Portugal. Later on, the President of the House of Trade was asked to participate and to seek the opinion of the Consulado de Sevilla. Ibid., at 595-9.

45 Antonio Fernández Delvás agreed to pay I50,000 ducats per year to the crown for a period of eight years, during which he might import up to 5,000 slaves, but never less than 2,500 annually. Crewmembers could be Portuguese, but on the condition that they were 'Old Christians'. Ships could travel from Angola and Cape Verde without passing through Seville, but their records had to be given back to the House of Trade in Seville or in Cadiz. Ships were authorized to disembark slaves in either Cartagena or Vera Cruz, but nowhere else.

46 Vila Vilar, supra note 2I, at 60.

47 Thomas, supra note 4I, at I65.

48 Scelle, supra note I2, vol. I, at 438, 439, 44I.
} 
actions of royal officials. This may partly explain why his asiento was the first slavetrading contract to run until its expiration (I623-I63I). More decisive, however, is the tacit agreement that was reached between the state and the merchant: The Spanish authorities, in desperate need of money, showed their good will towards the slave trader, who in turn did not shy from resorting to fraudulent activities to cover his expenses. ${ }^{49}$ That this equilibrium was fragile can be seen in the running of the next asiento (163I-I638). Although the contract had been meticulously drafted, the contractors saw their business hampered by the continuing malevolence of royal officials, and also by the monarch's whims, ${ }^{50}$ the war with Holland, ${ }^{5 \text { I }}$ and Portugal's loss of African possessions..$^{52}$ Another concern was the increasing power of the Inquisition throughout the Hispanic Empire against 'New Christians'. As a consequence, no Portuguese slave trader submitted a bid for the next contract. Former asentistas eventually offered to renew their contract, but on the condition that sanctions be made more effective against corrupt royal officials.

This proposal did not go through. The revolt of Portugal in December I640 and the recovery of its political independence prompted the Spanish king to break off all commercial relations with his neighbour: 'An angry and vindictive Philip IV, egged on by Casa de Contratación elements, took the only revenge immediately available to him; he cancelled the asiento and prohibited his American subjects from buying slaves from Portuguese sources. 53 For a decade, the Council of the Indies refused to sign large contracts for the slave trade, even though merchants from Portugal, Holland, and England offered their services. A flow of desperate memoranda about labour shortages came from virtually all American colonies. $^{54}$

\section{Foreign inVOLVEMENT AND THE INTRODUCTION OF 'JUDGES-CONSERVATORS'}

One such memorandum was presented to Philip IV during the negotiations that led to the next slave-trading arrangement. It sought to reinforce the claim that the limbo in which the legal slave trade had found itself had to stop: The Hispanic Empire's viability depended on the uninterrupted flow of an enslaved labour force. Allusion

49 Vila Vilar claims that no one respected the system (and this is why the trade worked). Vila Vilar, supra note 2I, at 6o. Scelle talks of 'good harmony' between the actors involved. Scelle, supra note I2, vol. I, at 453.

50 One telling example is found in Scelle, ibid., at 457-60.

5I The entry of Spain into the Thirty Years' War meant that the Caribbean became a 'war zone': Portuguese slave merchants lost 20 ships, mostly to the Dutch. Thomas, supra note $4 \mathrm{I}$, at I 78 .

52 For several years, the colonies of Portugal had been targets of opportunity for France and the Netherlands. The Dutch conquered the San Tomé Island in I599 and the colony of Angola in I64I. L. Rout, The African Experience in Spanish America. I502 to the Present Day (I976), 43.

53 Ibid., at 43. See for more details P. Schwartz, 'Panic in the Indies: The Portuguese Threat to the Spanish Empire, I640-I650', (I993) 2(I-2) Colonial Latin American Review I65.

54 It was not until I65 I that, realizing the great amount of losses incurred by the fact that the slave trade had been left in the hands of foreign interlopers, the Spanish crown entrusted (once again) the guild of Sevillian merchants with the supply of African labour in the Americas. However, they were ill equipped and unable to meet their obligations. See Scelle, supra note I 2, vol. I, at 49I-3. On the (slow) reaction of the Council of the Indies see E. Vila Vilar, 'La sublevación de Portugal y la trata de negros', (I976) 2(3) Ibero-amerikanisches Archiv I 7 I. 
was also made to the soaring number of foreign (mostly Dutch) interlopers taking over the trading networks in the Indies, and hence to the colossal financial losses incurred by the Spanish Royal Treasury. The Dominican priest who was negotiating on behalf of two interested contractors managed to convince the king of the viability of their project. In July I662, the Spanish administration signed an asiento with Domingo Grillo and Ambrosio Lomelín, two wealthy Genoese merchants living in Seville. Their I 9-point contract is a turning point in the evolution of the slave trade's legal framework, not least because it introduced a new judicial office, that of the juez conservador. 55

The Grillos - as they would be known in the 'New World' - were not just any other foreign merchants; they were bankers to the Spanish king and 'knew how to manipulate the strings of power at the Spanish court'. ${ }^{6}$ Their religion and nationality were also seen as an advantage. ${ }^{57}$ By then, most Western monarchical powers had acquired lands in the Americas as well as trading posts along the African coast; they had become slave traders and had learned from the Portuguese that the slave trade was the best way to access the American market. Indeed, the asiento trade was not only a business venture in its own right but also the only way by which foreigners could legally infringe on the Spanish colonial monopoly on trade. Smuggling goods or interloping, which had flourished on all sides, had proven to be a risky activity. With the asiento in hand, one could bring in manufactured commodities from Europe to sell to the settlers and purchase (slave-produced) cash crops in American fairs directly, instead of in Seville. Obtaining the asiento de negros thus became the subject of fierce competition among foreign contractors. Merchants from all over Europe 'longed for the Assiento itself, since by its possession the risks of clandestine trade might be avoided and the profits of middleman and principal united in their hands'. ${ }^{8}$ The crown had to decide to whom it would yield the lucrative trade. Given that Philip IV refused to do any more business with the Portuguese, those left were merchants from three competing - and problematic - colonial powers: Holland, England, and France. ${ }^{59}$ What Philip IV chose to do in 1662 is to turn to intermediaries.

He granted the Grillos the exclusive right to procure and sell slaves in the Spanish colonies in America (I662-I674). In comparison to what had been done previously, the two Genoese merchants were not to resell licences but to organize the slave

55 This contract is more concise than many of the trading agreements the crown had previously signed with the Portuguese, which had over 48 clauses. M. Vega Franco, El trafico de esclavos con América (Asientos de Grillo y Lomelín, I663-1674)(I984), 27.

56 F. Gaitán-Ammann, 'Daring Trade: An Archaeology of the Slave Trade in Late-Seventeenth-Century Panama (I663-I674)', Ph.D. diss., Department of Anthropology, Columbia University, New York, 20I 2, at I I9. They were the heirs of a solid, if declining, foreign banking tradition well implanted at the Spanish Habsburg court. See C. Sanz Ayán, Los banqueros y la crisis de la Monarquía de i640 (2013).

57 The former was deemed 'appropriate' and the latter, 'neutral'. Scelle, supra note I2, vol. I, at 496.

58 E. Donnan, 'The Early Days of the South Sea Company, I7 I I-I7 I8', (I930) 2 Journal of Economic and Business History 4I9, at 420.

59 'The first two were Protestant states, and the crown could not bring itself to trade openly with heretics. There remained only France, but that nation was at war with Spain until I659 Peace of the Pyrenees and would remain the sworn enemy of all Hapsburgs until I 700'. Rout, supra note 52, at 43-4. 
trade by themselves. ${ }^{60}$ The terms of the contract obliged them to ship a total of 24,500 piezas de Indias to the Indies in the space of seven years. One pieza de Indias referred, generally speaking, to a young adult male meeting certain specifications as to size, physical condition, and health. The very young, the old, and females were commodified as fractional parts of a pieza de Indias. As Philip Curtin noted, this measure was convenient for Spanish imperial economic planning 'where the need was a given amount of labour power, not a given number of individuals'. ${ }^{\text {I I }}$ It is also worth noting that the Grillos were not slave traders but investors; they needed to obtain their slaves from somewhere and were allowed to purchase them from 'any nation at peace with Spain' (article 8). In practice, they relied almost entirely on the supply of slaves provided by companies from northern Europe: The English Royal African Company (in Barbados and Jamaica) and the Dutch West Indian Company (in Curaçao) became their main subcontractors. ${ }^{62}$

To supervise the operations, Grillo and Lomelín could appoint up to three agents 'in any port or city where they might be needed' (article I I). These agents would be conceded all sorts of immunities and considerations by the Spanish administration. Most importantly, the contract specified that their agents could not be prosecuted by ordinary justice in the Indies. Instead, their agents' actions were to be overseen by 'un juez privativo, conservador de este asiento' - that is to say, a private judge, whose role was to defend or protect ('conservar') the interest of the asiento and to make sure that no slaves other than those of the Grillos would be introduced into the Indies during the contract's lifetime (article I2). These judges had to be Spanish nationals and chosen from the 'most disinterested servers of the Crown' (article I2). They were to be nominated by the Council of the Indies from a list of candidates submitted by the asentistas, who would also pay their salaries. These judges would have exclusive jurisdiction over all (civil and criminal) disputes arising out of the asiento, and their decisions could be appealed only to the Council of the Indies. In short, from I662 onwards, a specific dispute settlement mechanism was established to adjudicate all slave-trade matters.

The initial project that the Dominican priest had submitted to the king on behalf of the Grillos already envisaged the enrolment of private judges to guarantee the proper execution of the contract. Where had he got that idea from? At the time, many foreign merchants lived in Seville or Cadiz, the hub for the Indies trade. Although not directly involved (as it was prohibited) they participated indirectly in the trade and were familiar with the institution of the juez conservador. Businessmen doing

60 '[F]ar from limiting itself to the distribution of slave trading licences to dealers sailing from the coasts of Africa towards the New World, Grillo and Lomelin's firm would become the first exclusive slave trading concessionaire to operate directly from the Spanish Indies'. Gaitán-Ammann, supra note 56, at 6.

6I P. Curtin The Atlantic Slave Trade. A Census (1969), 22. The Grillos contract may not have been the first contract to use this measure, but it entrenched piezas de Indias as the legal unit for counting African slaves in a commodified form. See M.C. Naverrete, 'Los años inciertos del comercio esclavista a los reinos de Indias: I640-I680', (20I5) 45 Historia y espacio I I, at 25.

62 As the Grillos drew on markets within the Americas to meet their asiento commitments, commercial networks and distribution routes changed - direct voyages from Africa to Spanish America became uncommon, whereas Jamaica, Barbados, and Curaçao became the busiest slave trade depots in the Caribbean. D. Elis and D. Richardson (eds.), Extending the Frontiers: Essays on the New Transatlantic Slave Trade Database (2008), 35. 
colonial re-export were, indeed, members of corporative mercantile organizations ('nations') that had, since the early sixteenth century, striven to receive special privileges for their members. ${ }^{63}$ Each nation had a consul that was responsible for ensuring that treaties were complied with, for solving internal problems within the community, and for acting as their representative. By the mid-seventeenth century, however, consuls were gradually set aside; most nations came to benefit from a judge-conservator to settle lawsuits between their members and Spaniards or other foreigners. ${ }^{64}$ This private mechanism not only accelerated lawsuits and made them less expensive, but also made sure that the merchants' interests were duly taken into account. The nations' judges-conservators facilitated trade, notably by putting a stop to any excess on the part of the contraband inspectors. ${ }^{65}$

Even though the idea to transpose the juez conservador institution to the slave trade legal framework came from the merchants, it would be overly simplistic to see the introduction of private judges as a sign of the weakening of public power before the demands of private or corporate power. It is more appropriate to see it as an arrangement, as a compromise, or perhaps even as a 'convergence between the private interests of businessmen and the needs of the Crown's political economy'. ${ }^{6}$ Undoubtedly, the Grillos were eager to employ private judges to watch over the asiento. The new adjudicative system promised to be quicker and more efficient it is always easier to persuade someone to do something if you are paying that person. ${ }^{67}$ They also knew from previous asentistas that settlers and retailers in the Indies would not welcome their agents, and that royal officials would not be keen to assist them. That said, Madrid also supported the creation of a separate transnational judicial procedure. The authorities wanted - as much as the Grillos - the asiento to be successful, not least because the contractors had agreed to build ten shipyards for them on the Biscayan coast and to supply the shipyards in Havana, Campeche, and Santo Domingo with slaves and materials. That the asiento was connected to a shipbuilding program is precisely what had convinced the Spanish crown, in desperate need to refurbish its fleet but lacking the money to do so, to sign the agreement in the first place. To say it differently, the asiento inscribed the slave trade in a wider political economy that, from the state's perspective, commanded the

63 The literature on this topic has become considerable. For a classic see A. Girard, Le commerce français à Séville et à Cadix au temps des Habsbourg: contribution à l'étude du commerce étranger en Espagne aux XVIe et XVIIe siècles (I932). For a recent study see E. Crailsheim, The Spanish Connection. French and Flemish Merchant Networks in Seville (1570-1650) (2016).

64 In the seventeenth century, Spain signed a series of treaties of commerce with Holland, England, and France that admitted the indirect involvement of foreign merchants in colonial trade and strengthened their presence in Seville and Cadiz. The treaties granted them the same tariff as their competitors and special judicial protection through the nomination of a juez conservator. See S. Stein and B. Stein, Silver, Trade, and War: Spain and America in the Making of Early Modern Europe (2000), 58-67.

65 See A. Crespo Solana, 'El juez conservador: ¿Una alternativa al cónsul de la nación?', in M. Aglietti et al. (eds.), Los cónsules de extranjeros en la Edad Moderna y a principios de la Edad Contemporánea (2013), 22-33. F. Zamora Rodríguez, "Dar el cordero en guarda del lobo". Control hispánico sobre los consulados extranjeros durante el siglo XVII inicios del XVIII', (20I5) 30 Tiempos Modernos I.

66 A. García Montón, 'Corona, hombres de negocios y jueces conservadores. Un acercamiento en escala transatlántica (S. XVII)', (2015) 90 Revista de historia Jerónimo Zurita 75, at 77.

67 The Grillos provided them with an annual salary of 3,000 pesos - this was a considerable amount, higher for instance than the governors' salary (2,200 pesos per year). See Vega Franco, supra note 55, at I28-9. 
setting up of a separate jurisdiction. ${ }^{68}$ Besides, Madrid was very much aware of the indiscipline and venality of its colonial administration. ${ }^{69}$ The new system promised not to solve, but to circumvent the corruption and negligence that were endemic among royal officials in the Indies. Jueces conservadores would not be tributary to the colonial administration (as had been the case of jueces de comision), but rather to the Council of the Indies. In short, by taking power over both the legal and contraband trade off the hands of the viceroys and Audiencias, the state hoped to reinforce its authority. $^{70}$

The appointment of judges-conservators became an issue of primary importance. Soon after the contract was concluded, the Grillos put forth nomination proposals to the Council of the Indies to fulfil the new positions in key locations, both in Spain and in the Americas. ${ }^{7 \mathrm{I}}$ These positions came with prestige and power: Not only would the responsibilities of judges-conservators be comparable to those of the viceroys and Audiencias, but the issues they would address would affect a crucial sector of the economies of American ports and cities. For the asentistas, the best candidates were those who, in addition to having expertise and technical knowledge, would have the power to implement their decisions. They submitted the names of judges and public prosecutors of Audiencias, governors of islands or large cities, members of the Casa de Contratación, important clergymen and lawyers, etc. Some of the proposals were intensely debated. ${ }^{72}$ Within the Council of the Indies, the strongest opposition came from the fiscal (king's counsel or prosecutor), who contested the nomination of several governors or royal officers in the Indies on the ground that it was incompatible with their duty 'to defend the interests of ordinary justice and to combat fraud that could be done by the Grillos' factors'. ${ }^{73}$ In the end, though, the vast majority of the 4I appointed jueces conservadores were also members of the administration, which meant that the individuals charged

68 Another illustration can be found in the simplified and centralized scheme that the asiento set up to ensure steady revenue for the crown. The asentistas agreed to deliver 500 slaves per year to a predetermined shipyard tax-free (as they were destined to work for the state's shipbuilding program), while the 3,000 remaining would be introduced through the ports of Cartagena, Veracruz or Portobello at a taxation rate of roo pesos per piezas de Indias. At the end of each year, the Grillos' agents in Cartagena were to submit a complete report of the deliveries and tax payments to the senior royal official in that city. The state could expect to get a minimum of 300,000 pesos in tax money from the Grillos each year, regardless of the actual number of slaves the Genoese would succeed in shipping, and with limited involvement of the colonial administration. It was anticipated that by the end of the contract, the Royal Treasury would have received at least 2,I00,00o pesos.

69 M. Bertrand, Grandeur et misère de l'office. Les officiers de finances de Nouvelle-Espagne (XVII-XVIIIe siècles) (I 999), at 8-9.

70 'Taking the activities of the asiento away from ordinary courts was seen as a remedy to the support and indulgence of local American authorities with regard to the illegal traffic of slaves that adversely affected fiscal recollection'. García Montón, supra note 66, at Io6.

${ }_{71}$ The locations where the asentistas asked to place judges-conservators are highly instructive. For instance, the Grillos installed some of their 'most capable agents' in the city of Panama - a crucial commercial location in the Hispanic Empire, through which all the silver bullion coming up from the mines of Potosi was channelled on its way to Spain. The city also served as a port of transit for all the African captives who were transported to Peru - by far the largest slave market of all the Spanish colonies in the Americas. See Gaitán-Ammann, supra note 56.

72 Alejandro García Montón has found that, out of the 4I nomination proposals that were presented by the Grillos over the years, 30 were accepted and eight were rejected. García Montón, supra note 66, at 89.

73 AGI, Leg 2834, Consulta del Consejo de Indias. 08-VIII-I664, cited in García Montón, supra note 66, at 89. 
with ensuring law and order in the colonies were also charged with protecting the asiento. $^{74}$

What is striking about the wording of the 1662 contract is the way it portrays the merchants and the state as working hand in hand. Were they not equally interested in combating smuggling?75 It is almost as if the asiento was meant less to allow the Grillos to do their business than to enhance the power of the state. In addition to regaining its maritime power, the state would finally respond to the colonies' need for a labour force and benefit financially from the trade. Not everyone was convinced of this, though. The fiscal of the Council of the Indies proved to be a particularly fierce opponent of the Grillos, whom he believed had been conceded 'outrageous trading benefits that were detrimental to the crown'. ${ }^{7}$ He contested the contracts the Grillos concluded with Dutch and English chartered companies, considering the transactions to be endangering the security of the Empire and self-defeating for colonial commerce overall. ${ }^{77}$ He persuaded the Council of the Indies to annul these contracts in I663, which resulted in major disruptions to the trade and delays in the shipbuilding program. This was followed by endless administrative hurdles and lawsuits, most of which ended only as a result of an agreement the Grillos signed with the crown several years after the end of the asiento. ${ }^{78}$

\section{The JeAlousy of TRADE}

Throughout the seventeenth century, Portugal, France, England, and Holland developed their overseas empires largely by means of commercial companies. It was only a matter of time before they would seek to exploit commercial opportunities in the Americas. ${ }^{79}$ Yet, Spain tried to avoid contracting directly with foreign chartered companies for as long as possible, given that their 'quasi-national character ... would result in political complications that endangered not only European politics

74 This is why Robert Zaugg considers judges-conservators to be 'serving two masters' ('serviteurs de deux patrons'). R. Zaugg, 'Entre diplomatie et pratiques judiciaires: la condition des étrangers sous l'ancien régime napolitain', (2013) I7 Revue d'histoire maritime 32 I, at 328.

75 Article 6 of the contract foresaw that judges-conservators would play a crucial role in this matter: they were to supervise the Grillos' factors and be involved in all steps of the procedure. They could be present in Spain during the vessels' anchorage inspections and in the colonies when slaves were disembarked, measured, and sold. They were entitled to inspect any ship anchoring in the Indies and ask for administrative measures to be taken against corrupt royal officials. On the powers of judges-conservators, see García Montón, supra note 66 , at I06.

76 Gaitán-Ammann, supra note 56, at 63.

77 The asentistas signed, in I662-I663, a series of contracts with foreign chartered companies: one with the Dutch West India Company for I,200 to 2,000 piezas de Indias to be delivered to Curaçao; the other with the English Royal African Company for 5,000 slaves to be delivered in Jamaica and Barbados every year (so 35,000 in total). On the annulment and suspension of these contracts, see Vega Franco, supra note 55, at 39-49.

78 The Dutch are the ones who emerged relatively unscathed from this situation. All subsequent asentistas employed the West Indian Company for supplying their ships in Curaçao, and used banks in Amsterdam for their financing. This tendency culminated in I685, when a Protestant banker and agent of the Dutch Company, Balthasar Coymans, was granted the asiento. On this asiento, see J. Postma, The Dutch in the Atlantic Slave Trade. I660-I8I5 (I990), at 4I-8; I.A. Wright, 'The Coymans Asiento (I685-I689)', in P.J. Blog and N. Japikse (eds.), Bijdragen voor Vaderlandsche Geschiedenis en Oudheidkunde (I924).

79 Rolando Mellafe explains how the slave trade had become highly complex and costly, requiring a capital investment that only commercial companies could make, at the same time that the Spanish empire deteriorated economically. R. Mellafe, Negro Slavery in Latin America (I975), 50. 
but also the integrity of overseas colonies' ${ }^{80}$ Hence Spanish authorities persisted, in I692, in granting the slave trade monopoly to a national, a private entrepreneur from Caracas named Bernardo Marín de Guzmán, while knowing that his main sponsor was the Portuguese Cacheu Company. Problems arose upon Guzmán's unexpected death in I695. Representatives of the Cacheu Company petitioned Madrid, arguing that the operation should revert to them. The Council of the Indies rejected their demand, insisting that arrangements made between Guzmán and them were in no way binding upon the Spanish government. ${ }^{81}$ But to whom should the asiento be otherwise granted? As Leslie Rout summed up well, Spain 'no longer tolerate[d] the Dutch, was frightened of the English, and was at war with the French - the only potential supplier left was Portugal'. ${ }^{22}$ Once the Cacheu Company proposed to advance a desperately needed 200,000 pesos loan, Charles II overruled the Council of the Indies and agreed to sign a contract with Manuel Ferreira de Carvallo in the name of the Portuguese company. The latter, benefitting from generous contractual terms, launched a brief but apparently profitable trade with the Spanish Indies (I696-I70I). ${ }^{83}$

What I want to highlight with this episode is that Spain came to use the asiento as an indirect method of applying political pressure and also, eventually, as a bargaining chip in diplomatic settings. ${ }^{84}$ The slave trade had become part of a global market competition, whereby states sought to establish trading monopolies for their merchants. ${ }^{85}$ For Spain, this meant opening the door to more and more diplomatic interventions in the operation of the slave trade. Conversely, foreign commercial companies gradually secured terms that were more and more favourable to them. They also worked to strengthen the position of the juez conservador, even though this did not automatically play in their favour. They had to deal with another key actor - the Council of the Indies - who had gained additional leverage by becoming the appellate body.

Take for instance the I696 asiento. It broadened the jurisdiction of judgesconservators, especially with regard to the seizure of foreign vessels, and reaffirmed their independence (article 9). It also stated that the asiento holder had the power to appoint, remove, and displace judges-conservators at pleasure (article 8 ). ${ }^{86}$ These provisions enabled the company to take disciplinary action against judges who tended to privilege the crown's interests, ${ }^{87}$ and to complain against the wrongful behaviour

Woindl, supra note II, at 237.

8I For their reasoning, see Scelle, supra I 2, vol. 2, at 3I-4.

82 Rout, supra note 52, at 46.

83 For the generous conditions given to the company in the contract see Scelle, supra note I2, vol. 2, at 48-53.

84 Scelle, supra note 18 , at 626 .

85 On the 'jealousy of trade' as a particular conjunction between politics and the economy, when commercial trade was subservient to political considerations see I. Hont, Jealousy of Trade: International Competition and the Nation-State in Historical Perspective (2005).

86 This article was added in light of the difficulties encountered by past asentistas. For the difficulties the Grillos faced in these matters see García Montón, supra note 66.

87 In I 700, the company invoked article 8 of their contract to revoke one of their judges-conservators, the alcalde of Mexico, whom the company perceived to be more attuned to the crown's interests than to theirs. On this incident (and an implicit critique of the company), see Scelle, supra note I2, vol. 2, at 56-7. 
of Spanish royal officials. ${ }^{88}$ Most of the tensions, however, crystallized around the relations between the Cacheu Company and the Council of the Indies. The former had a number of complaints and appeal procedures pending in perpetuum in front of the latter, including an important reclamation complaint following the sack of Cartagena. Upon hearing that the Council allowed other merchants to bring slaves to Santo Domingo - a clear violation of the monopoly - the Portuguese ambassador in Madrid got involved, and asked for the setting up of a special Junta composed of three 'dispassionate men'89 to replace the Council of the Indies. His proposition was rejected. Shortly after, the president of the Council, who was also the asiento's chief judge, died. Unhappy with the next-of-kin, the company tried to appoint another member of the Council, who seemed more sympathetic to its concerns, as chief judge. The Council opposed this nomination, stating (against a strict wording of article 8) that control over the appointment and removal of judges remained ultimately in its hands. In its decision, the Council stressed that the company had failed to fulfil its obligations while profiting from unprecedented contraband trade..$^{90}$

Needless to say, the relations between Portugal and Spain had grown extremely tense when Charles II died in I 700. In his last testament, Charles II left his kingdom to Philip of Anjou, grandson of Louis XIV. As soon as Philip V was enthroned, his grandfather took a firm hand in Spanish foreign affairs. The Portuguese asiento was dissolved and negotiations took place between France and Portugal to settle disputes related to its liquidation. In I70I, a new asiento was concluded with Jean-Baptiste Ducasse in favour of the French Royal Company of Guinea. These contractual terms constituted 'the most favourable proffered to any supplier yet'. ${ }^{9 \mathrm{I}}$ The company was to bring 48,0oo piezas de Indias over a ten-year period and it could disembark them at any American port not specifically prohibited, including Buenos Aires. Nonetheless, the company's activities did not run smoothly, in part because of the hostility shown by the Council of the Indies. While the new king believed that both he and Spain would profit from the change in asentistas, the Council of the Indies vigorously opposed what it perceived to be French interference in Spanish internal affairs. Its members were outraged by a provision of the asiento that took their jurisdiction away in case of wrongdoings by royal officials and assigned it to the king. ${ }^{92}$ Unsurprisingly, as the activities started, the Council did nothing to stop colonial officials from harassing the Guinea Company at every turn. It also took measures that went actively against

88 An important dispute arose in Cartagena, the company's main distribution centre, following the nomination of Juan Días Pimienta as the city's governor in I699. In six months, the governor closed the company's operation in the port and arrested its chief agent for dealing in contraband goods and conspiring to defraud Spain of the duties to be paid on incoming slaves. Furious, the company "charged Días Pimienta with theft and extortion, sought his dismissal, and presented a demand to Madrid for 752,00o pesos in compensation for damages'. Rout, supra note 52, at 47. Rout considers that Días Pimienta's charges were, in retrospect, largely justified.

89 Scelle, supra note I2, vol. 2, at 64 .

90 Ibid., at 58.

9I Rout, supra note 52, at 49. The company advanced 200,000 pesos to the Spanish government for this privilege and, in return paid a duty that was 4.5 per cent lower than the one that the Portuguese had been granted. Furthermore, a rebate of $\mathrm{I} 7$ per cent of the duties was to be paid in any year in which 4,800 piezas were delivered.

92 Article 20 of the asiento (which can be found in A. Del Cantillo, Tratados, convenios y declaraciones de paz y de comercio que han hecho con las potencias extranjeras los monarcas españoles de la Casa de Borbón (I843), 35). 
the asiento. ${ }^{93}$ Outraged by such obstructionism, French diplomats intervened with Philip V. In I 703, they managed to sideline the Council of the Indies by establishing what the Portuguese had wanted, a special Junta, composed of three members whose supplementary salary the company would pay. ${ }^{94}$ But the Junta did not play much of a role. It was dissolved by decree in 1708 when the Spanish king, gaining some autonomy, reassigned all asiento affairs to the Council of the Indies. ${ }^{95}$

The award of the asiento to the French in I70I is said to have been an important motive for the outbreak of the War of the Spanish Succession (I702-I7I3). The British felt deprived of their participation in the lucrative slave-trade. When the peace negotiations started, the British made it clear that they wanted the asiento. ${ }^{96}$ On 26 March I7I3, representatives of Spain and Britain signed the Asiento Treaty by which the British were to provide I44,000 piezas de Indias over a 30-year period under the same conditions that the Portuguese and French had enjoyed, and more. ${ }^{97}$ In return for handing the slave trade monopoly over to the British, Philip V kept himself on the throne of Spain; he also obtained a quarter of the company's business and received a 200,000 pesos loan, which he only had to refund after 20 years. For the South Sea Company, which had just been created, the contract offered very generous conditions; it could send a 500-ton ship with consumer goods from London to Portobello once a year - the so-called 'annual ship'. Among the company's other privileges was the strengthening of the dispute settlement mechanism. The company had the power to name as many jueces conservadores as they saw fit (article I3). More importantly, the treaty provided for the establishment of a reduced advisory or appellate body to supervise the asiento (article 38). The Junta del asiento, as it was called, was an executive committee composed of three jointly appointed ministers; it would advise the Spanish king on all petitions or legal disputes concerning the slave trade and annual ships. Lord Lexington, British ambassador to Madrid and a key negotiator of the treaty, reported that it was 'the best Asiento that was ever made and a more advantageous treaty of commerce [than] any nation yet had'.$^{98}$

The economic and political importance of the British asiento has been well established by historians. ${ }^{99}$ They have also shown that what British investors once called 'the feather and flower of our trade' ${ }^{\text {Ioo }}$ did not live up to expectations, and

93 For instance, in June I702, the Council of the Indies prohibited the sale of Mina or Cabo Verde slaves in Indies ports. The company protested this prohibition, and merchant groups in the Indies also demanded its rescission, but the council refused to retreat from its position on the ground that these slaves were 'exceedingly barbarous'. As Rout stressed, the fact that 'both the Portuguese and Dutch had supplied these slaves to Spanish America prior to the award of the asiento to the French appears to have been a consideration the council conveniently overlooked'. Rout, supra note 52, at 5I. The king had to intervene to resolve the matter.

94 Scelle, supra note I2, vol. 2, at 225.

95 A. Colin, 'L'Asiento français (I7OI-I 7I3) et anglais (I7 I3-I750) et le commerce franco-espagnol vers I 700 à I730', (I929) I7(3/4) Revue d'histoire économique et sociale 403.

96 That the peace agreement was signed the day after the conclusion of the commercial agreement shows how important the award of the asiento had been for the British. Scelle, supra note I 2, vol. 2, at 570.

97 On the advantages that the British obtained, see Scelle, supra I 2, vol. 2, at 552-72.

98 S. Carmona, R. Donoso and S. Walker, 'Accounting and International Relations: Britain, Spain, and the Asiento Treaty', (2010) 25 Accounting, Organizations, and Society 252, at 257.

99 For a classic see J. McLachlan, Trade and Peace with Old Spain, I667-I 750 (I940).

roo W. Wright, An Address to the Proprietors of the South-Sea Capital (1732), I3. 
have spent quite some time explaining 'the utter failure of the South Sea Company ... to fulfil the terms of the asiento'. ${ }^{\text {IOI }}$ But they have overlooked the dispute settlement mechanism - to what extent did it ferment the 'deep and abiding distrust' ${ }^{\text {'02 }}$ that characterized Anglo-Spanish relations? There are records where the company accused judges-conservators of partisanship, saying that they were 'of little service and often oppressors instead of protectors of the Company's privileges' ${ }^{\text {I03 }}$ At the same time, the company complained that other tribunals persisted in claiming jurisdiction over slave trade cases; consequently, 'the Judge Conservator's power is almost wholly annihilated, though the Company at the same time pays them very considerable salarys'. ${ }^{\text {I04 }}$

More studies would be needed to assess the role of the dispute settlement mechanism. From the viewpoint of British investors sitting in London, it may be true that the adjudication of disputes merely confirmed their 'sense of grievance and injustice'. ${ }^{05}$ But it could also be the case that when judges-conservators ruled over disputes in the colonies, they were careful to strike a balance between all the interests at stake. ${ }^{\text {I06 }}$ As for the Junta del asiento, it resolved many administrative, financial, and technical disputes arising from the slave trade operation, ruling sometimes in favour of the asentistas, ${ }^{107}$ sometimes against them. ${ }^{108}$ The Junta also had to advise the king upon highly sensitive cases involving illicit commerce done by the South Sea Company and illegal seizures of the company's vessels by guarda costas (i.e., privately fitted ships that received remuneration from the sale of the prizes they captured). Besides, one should be reminded that the running of the asiento was hindered by military conflicts between England and Spain. When hostilities broke out in I7 I 8, I7 26, and again in 1727 , most of the company's effects were confiscated by Spanish officials and employees were expelled from America. These matters were resolved by means of diplomacy instead of adjudication. ${ }^{\text {Io9 }}$

ror A. Swingen, Competing Visions of Empire. Labor, Slavery, and the Origins of the British Atlantic Empire (2015), I95. For a summary of the various explanations, see D. Baxter, 'Asiento', in L. Frey and M. Frey (eds.), The treaties of the War of the Spanish Succession. A Historical and Critical Dictionary (1995), I9.

I02 C. Palmer, Human Cargoes. The British Slave Trade to Spanish America, I 700-I739 (I98I), Io.

I03 Ibid., at I34.

I04 Ibid. Judges-conservators also saw their jurisdiction contested by local authorities. In $\mathrm{I} 727$, for instance, the viceroy of Mexico ruled that the company's judges only had passive jurisdiction, meaning that they could be involved only when the company was a defendant. Since, as a large-scale creditor, the company was almost always a plaintiff in its actions, 'this was to deny it redress'. P. Woodfine, Britannia's Glories: The Walpole Ministry and the I739 War with Spain (I998), 79.

I05 Palmer, supra note I02, at I30.

Io6 This is my reading of V. Gardner Sorsby, 'British Trade with Spanish America Under the Asiento, I 7 I 3-I 740', $\mathrm{PhD}$ thesis, University of London, I975.

I07 For instance, in I717, the Junta ruled in favour of the asentista who complained about the imposition of unauthorized taxes, duties and charges by local officials in Spanish America. The Junta agreed that such taxes were harmful to business and ordered the charges to be removed. Palmer, supra note I02, at I30-I.

Io8 The Junta was involved in the disputes concerning the annual ship, and in the refusal to issue the company's licence to send such ship in I7I8 and I724. See R. Donoso Anes, 'Los navíos anuales de permiso del asiento de esclavos con Inglaterra hasta la Feria de Portobelo de I73I', (2008) 4 Revista de Historia Naval I.

I09 It was within this tense atmosphere that captain Robert Jenkins appeared in London in 1738 and presented his severed ear in a jar to Parliament. The tale is that his ship Rebecca had been seized by a Spanish guarda costa in I 73I and his ear had been cut off. The story angered members of the Commons and enflamed British public opinion. The following year, Britain commenced hostilities in what became known as the War of Jenkins' Ear (but known as guerra del asiento in Spain). Though the company's asiento nominally lasted another decade, 
The I7I3 Asiento Treaty marks the peak of the slave trade's international arbitration system. ${ }^{\text {IIO }}$ The turn to international commercial arbitration culminated in the Asiento Treaty concluded between Britain and Spain, which provided for the appointment of private judges and the creation of an appellate body. The South Sea Company did not need to use diplomatic protection as a means of vindicating its rights. A parallel judicial procedure had been created all the way through to adjudicate slave trade-related disputes. By that time, judges-conservators had become key actors in the slave trade operation, both in the colonies and on the Iberian Peninsula. Their remuneration was a cost the South Sea Company agreed to bear; in fact, their salaries were the highest salaries paid by the company - more than those received by factors (or agents), guards, physicians, attorneys, etc. ${ }^{\text {II }}$ Evidence suggests that judges-conservators from past asientos remained in place, so that a small pool of legal experts gradually came to enjoy significant influence on the running of the slave trade.

\section{Conclusion}

What can we learn from this moment in history? First of all, it comes as a reminder that the slave trade was a legal system through and through. This is a much-needed reminder since the question of slavery has had a particular resonance among international lawyers. The abolition of the slave trade has often been presented as 'the most successful episode ever'II2 in the history of international law. International lawyers still tend to look at slavery in terms of its abolition, thereby suggesting that international law stepped in only to abolish the slave trade in the nineteenth century. ${ }^{I I 3}$ This gives an excessively positive view of the law (and of lawyers), as if they always stood on the side of today's humanitarian sentiments. Such a view is not only naïve, it is also harmful. In reality, legal rules and institutions are often created to advance the purposes of ambitious men who have made possible and perpetuated some of the worst injustices - injustices that we, lawyers, might not see (or want to see) when they are being committed.

that war marked the rupture of the contract. "The British did not lose interest in the trade to Spanish (or French) America with the asiento's demise, but after I739, they would seek alternate ways of using the slave trade to wrench foreign markets open to trade.', G.O'Malley, Final Passages. The Intercolonial Slave Trade of British America, I6I9-I807 (2014), 263.

II In I750, Britain gave up the asiento and the Spanish authorities 'restore[d] the slave trade to the sphere of internal law from which it should never have left'. G. Scelle, 'Une institution internationale disparue: l'assiento des nègres', (I906) I3 RGDIP 357, at 395.

in Palmer, supra note I02, at 60. The highest salary was paid to the president of the Council of the Indies; as 'chief judge' of the asiento he received 2,00o pesos a year. Members of the Junta del asiento received 600 pesos a year. In the colonies, annual salaries of judges-conservators ranged from 2,000 to 3,000 pesos.

II $J$. Martinez, The Slave Trade and the Origins of International Human Rights Law (2012), I3. This view typically stresses that slave trade and slavery are among the few prohibitive norms of jus cogens, thereby portraying a heroic image of the discipline. For a much more nuanced approach see J. Allain, Slavery in International Law. On Human Exploitation and Trafficking (2013).

II3 This point has been forcefully made by F. Mégret in 'Droit international et esclavage: pour une réévaluation', (2013) I 8 African Yearbook of International Law I 2 I. 
The slave trade's legal regime is also instructive in two other ways. ${ }^{\text {II } 4}$ First, it invites us to rethink the history of international arbitration in commercial and investment matters, and to pay closer attention to 'private' dimensions of formal and informal imperialism. When scholars claim that 'international investor-state arbitration is now acknowledged by the international investment community as the standard means of last resort, at least judicially speaking, in resolving complex crossborder investment disputes in a globalized economy, ${ }^{\mathrm{II}}{ }^{5}$ history tells us that such institutional practice is not unprecedented. Back in the early modern period, public and private actors responded to the practical and judicial needs of an increasingly complex, bureaucratic and global trade by setting up a transnational arbitration mechanism. What is more, history tells us that this process was not inevitable, self-evident or even smooth. The alliance between the state and the merchants, in particular, was never an easy one. It was a relationship full of compromises and intense lobbying, in which each tried to draw the other into service. This becomes palatable when looking at the dispute settlement mechanism that was set up over time. This mechanism was neither the result of private power hegemony nor the result of a mutual conspiracy between the state and the merchants. Rather, it was the product of constant negotiations and shifting alliances, and also at times of outright hostility and suspicion between them - in other words, it was the product of a relationship 'based less in mutual benefit than mutual dependence'. ${ }^{\text {in6 }}$

Second, a study of the slave trade's legal regime allows us, in a mirroring effect, to question the idea that today's dispute settlement mechanism was conceived 'as a means to depoliticize international investment law' ${ }^{\text {II7 }}$ One can often read that contemporary international investment arbitration was designated 'to extricate investment disputes from national courts and gunboat diplomacy, entrusting them instead to a neutral law-bound process' ${ }^{\text {'I } 8}$ or, similarly, that it 'offers a specialised and neutral forum to hear disputes arising between foreign investors and the host state of their investments'. ${ }^{\text {I9 }}$ Such claims imply not only that private arbitration would be a more neutral avenue than domestic courts for investment-related issues,

Ir4 On the possibility of bridging the historical investigation and the contemporary commentary, and in particular on the legitimate role of anachronism in international legal method see A. Orford, 'On International Legal Method', (2013) I London Review of International Law I66, and A. Orford, 'The Past as Law or History? The Relevance of Imperialism for Modern International Law', IJIL Working Paper 20I 2/2.

in T.R. Braun, 'Globalization: The Driving Force in International Investment Law', in M. Waibel et al. (eds.), The Backlash Against Investment Arbitration. Perceptions and Reality (2010), 496.

Ir6 P. Stern, 'Companies: Monopoly, Sovereignty, and the East Indies', in P. Stern and C. Wennerlind (eds.), Mercantilism Reimagined: Political Economy in Early Modern Britain and Its Empire (2014), I8o.

I17 C. Rogers, 'The Politics of International Investment Arbitrators', (2013) I2 Santa Clara Journal of International Law 223, at 223.

II8 Ibid. The claim that investment arbitration is 'neutral' is widespread in academic, practitioner, and policy literature. See for instance International Centre for Dispute Resolution, ICDR Handbook on International Arbitration and ADR (2017); Latham \& Watkins, 'Guide to International Arbitration 2014', available at www.lw.com/thoughtleadership/guide-to-international-arbitration-20I4. Other references can be found in G. Van Harten, 'Investment Treaty Arbitration, Procedural Fairness, and the Rule of Law', in S. Schill (ed.), International Investment Law and Comparative Public Law (2010).

II9 J. Billet, International Investment Arbitration. A Practical Handbook(20I6), 2 I. Even more critical, Gus Van Harten writes that arbitration 'offers a neutral and impartial forum in which to resolve investor-state disputes as a basis for protecting foreign-owned assets and ensuring the rule of law'. G. Van Harten, 'Arbitrator Behaviour in Asymmetrical Adjudication: An Empirical Study of Investment Treaty Arbitration', (2012) 50(I) Osgoode Hall Law Journal 201, at 2 I 3. See also S. Schill, 'Private Enforcement of International Investment Law: Why We 
but also that relations between host states and private investors would be technical, located outside material values, political interests, and democratic debates. They presuppose that what goes on in international investment law is 'business as usual' and that the work of arbitration tribunals is a matter of legal dogma,i.e., they only make sure that legal relations between public and private actors can unfold normally.

This is clearly over-simplistic. ${ }^{\text {I20 }}$ There is nothing neutral, normal or apolitical in investment law and adjudication. Relations between states and private investors are always thoroughly political: Investment treaties were typically signed between developed (capital-exporting) states and developing (capital-importing) states and most cases are still being brought by investors from capital-exporting states against capital-importing states. ${ }^{\text {I2I }}$ What is more, investments affect vital activities or sectors for national societies, activities that have been - and still are - the object of debates. Indeed, disputes span a wide range of environmental, labour, and health issues (such as the non-extension of operating licences for waste disposal, the control and ban of harmful substances, the implementation of anti-tobacco policies ... ) $)^{\mathrm{I22}}$ including constitutional issues relating to the scope of the legislator's emergency powers. ${ }^{\text {I23 }}$ In such circumstances, to say that arbitration tribunals are 'neutral' is itself a political claim, a claim that seeks to normalize power relations and interests by leaving fundamental premises unseen and unquestioned. The process is 'neutral' only if we believe that freedom to invest, freedom to extract resources (including living species), and freedom to repatriate capital as understood and agreed upon by a network of private actors and national elites are 'normal' and sitting outside of politics. What the turn to arbitration tribunals makes possible is for such premises to remain unseen or untouched - they are never discussed, they are taken for granted and accepted as normal, inevitable, and even fair.

It is precisely the perversity of this normalization process that history brings to the fore. The arbitration mechanism that was put into place in the sixteenth, seventeenth and eighteenth centuries only made the slave trade more acceptable. Judges-conservators worked from within the system, they never questioned the

Need Investor Standing in BIT Dispute Settlement', in M. Waibel et al. (eds.), The Backlash Against Investment Arbitration. Perceptions and Reality (2010), 3 I.

I20 Part of this critique is captured by the argument that because investment treaty arbitration is an exercise in public law, it should take into account the underpinning public purpose of economic and social development for participating states' populations and economies. For an overview see C. Foster, 'A New Stratosphere? Investment Treaty Arbitration as “Internationalized Public Law”, (20I5) 64 ICLQ 46r. For a similar argument made from a different approach see C. Cutler, 'Human Rights Promotion Through Transnational Investment Regimes: An International Political Economy Approach', (2013) I(I) Politics and Governance I6.

I2I With the usual caveat that this trend is slowly changing. See A. Roberts, 'Clash of Paradigms: Actors and Analogies Shaping the Investment Treaty System', (2013) I07 AJIL 45, at 76.

122 See Técnicas Medioambientales Tecmed S.A. v. United Mexican States, ICSID Case No. ARB(AF)/oo/o2, Award of 29 May 2003; Metalclad Corp v. United Mexican States, ICSID Case No. ARF(AF)/97/I (NAFTA), Award of 30 August 2000; Methanex Corporation v. United States, UNCITRAL (NAFTA), Award of 3 August 2005; Chemtura Corporation (formerly Crompton Corporation) v. Government of Canada, UNCITRAL (NAFTA), Award of 2 August 20 Io; Philip Morris Brands Sarl, Philip Morris Products S.A. and Abal Hermanos S.A. v. Oriental Republic of Uruguay, ICSID Case No. ARB/Io/7, Award of 8 July 2016.

123 See CMS Gas Transmission Co. v. Argentine Republic, ICSID Case No. ARB/o I/8, Award of I 2 May 2005; Continental Casualty Company v. Argentine Republic, ICSID Case No. ARB/03/9, Award of 5 September 2008; National Grid plc v. Argentine Republic, UNCITRAL (NAFTA), Award of 3 November 2008. 
legitimacy or legality of slavery. ${ }^{\text {I24 }}$ The unspoken premise on which they worked was that human exploitation was 'normal'. Human beings could be bought in Africa, carried on slave ships, and sold in the Americas - African slaves were, after all, a precious resource and one indispensable element of the triangular trade. It is only based on these premises that private judges could do their work and examine whether slave-trading activities respected the contractual conditions found in the successive asientos de negros. My point, to say it differently, is that the arbitration process only reinforced the logic of slave commodification. Take the high mortality rates during the Middle Passage. Oddly enough, it was the slaves' humanness that was the problem: Slaves were not commodities like cotton or silver, they had to remain alive for the commerce to be lucrative. How did judges-conservators respond? They made sure that Spanish regulations on the carrying capacity of the ships were implemented, that sufficient amount of provisions be brought along, and that medical care be on board. Their objective was not to preserve life but to diminish the morality rate in a way that was not too costly for the benefits.

In short, arbitration tribunals do not constitute a 'neutral' forum sitting outside of 'politics'. They address questions regarding the organization of economic life and the distribution of values that remain profoundly debated in the societies in which they operate. Whether in the slave trade of the sixteenth-seventeenth centuries or in the globalized economy of the twentieth-twenty-first centuries, arbitration tribunals allow far-reaching interventions in the lives of political communities.

\footnotetext{
I24 My critique is not about the moral quality or specific actions of professionals; it is systemic in a way approaching M. Koskenniemi, 'It's not the Cases, It's the System: M. Sornarajah, Resistance and Change in the International Law on Foreign Investment', (2017) I 8 Journal of World Investment \& Trade 343.
} 